\title{
Catalytic Conversion for Hydrogen Sulfide
}

\section{Aerosol and Air Quality Research}

\author{
Xiaoyu Zhou ${ }^{1}$, Xiaoning Pei $^{1}$, Rui Wang ${ }^{1 *}$, Tiansheng Zhao ${ }^{2}$ \\ ${ }^{1}$ School of Environmental Science and Engineering, Shandong University, Qingdao 266237, \\ China \\ ${ }^{2}$ State Key Laboratory of High-Efficiency Utilization of Coal and Green Chemical Engineering, \\ Ningxia University, Yinchuan 750021, China
}

\section{ABSTRACT}

In this study, a series of transition metal mono-substituted heteropoly compounds $\mathrm{H}_{7} \mathrm{PMO}_{11} \mathrm{MO}_{39}$ $\left(\mathrm{M}=\mathrm{Co}^{2+}, \mathrm{Mn}^{2+}, \mathrm{Ni}^{2+}\right.$ and $\left.\mathrm{Zn}^{2+}\right)\left(\mathrm{HPMo}_{11} \mathrm{M}\right)$ and single-absent heteropoly compounds $\mathrm{H}_{3} \mathrm{PMo}_{11} \mathrm{O}_{39}$ ( $\mathrm{HPMO}_{11}$ ) were prepared for highly effective removal of hydrogen sulfide $\left(\mathrm{H}_{2} \mathrm{~S}\right)$ from gas stream. The heteropoly compounds were characterized Fourier transform infrared spectroscopy (FT-IR), elemental analysis and scanning electron microscopy (SEM). The results confirmed that the transition metal ions successfully replaced the $\mathrm{Mo}$ atom. $\mathrm{H}_{7} \mathrm{PMO}_{11} \mathrm{CoO}_{39}$ showed that the outstanding desulfurization capacity and the $\mathrm{H}_{2} \mathrm{~S}$ removal efficiency can reach more than $90 \%$ for $3 \mathrm{~h}$. Besides, after regeneration, the desulfurization capacity of $\mathrm{H}_{7} \mathrm{PMO}_{11} \mathrm{CoO}_{39}$ towards $\mathrm{H}_{2} \mathrm{~S}$ only a drop of $5.11 \%$ of the initial desulfurization capacity. Optimization experiments demonstrated that $\mathrm{H}_{7} \mathrm{PMO}_{11} \mathrm{CoO}_{39}$ had the ideal desulfurization performance under the condition of low $\mathrm{H}_{2} \mathrm{~S}$ concentration or high dosage of $\mathrm{H}_{7} \mathrm{PMO}_{11} \mathrm{CoO}_{39}$. An appropriate temperature of $25^{\circ} \mathrm{C}$ is necessary for high removal efficiency. The optimum $\mathrm{pH}$ value for desulfurization is 5 . The kinetic data can be well described by pseudo-first-order kinetic model. The desulfurization products were proved to be $\mathrm{S}$ and $\mathrm{SO}_{4}{ }^{2-}$ based on X-ray photoelectron spectroscopy (XPS) characterization results.

Keywords: Transition metal ions, Heteropoly compounds, $\mathrm{H}_{2} \mathrm{~S}$, Desulfurization

\section{INTRODUCTION}

\section{OPEN ACCESS}

Received: April 12, 2021

Revised: July 7, 2021

Accepted: July 10, 2021

${ }^{*}$ Corresponding Author: wangrui@sdu.edu.cn

\section{Publisher:}

Taiwan Association for Aerosol Research

ISSN: $1680-8584$ print

ISSN: 2071-1409 online

Copyright: The Author(s). This is an open access article distributed under the terms of the Creative Commons Attribution License (CC BY 4.0), which permits unrestricted use, distribution, and reproduction in any medium, provided the original author and source are cited.
Heteropoly compounds (HPCs) have been widely used in various organic and catalytic synthesis reactions. This is because the HPCs have high catalytic activity, stable structure, redox and redox reversibility, excellent selectivity, and can be used as homogeneous and heterogeneous catalysts. When the central heteroatoms in the HPCs are replaced by transition metal ions, a wide variety of substituted HPCs can be generated. This expands the field of catalytic reduction of HPCs. In recent years, transition metal-substituted heteropoly compounds have attracted the attention of researchers at home and abroad and become a hot research field (Weakley and Malik, 1967). The vacant heteropoly compound anions are similar to multidentate ligands, with two or more atoms that can provide lone electron pairs. Therefore, people can synthesize substituted heteropoly compounds with transition metal ions (Bi et al., 2004; Proust et al., 2008). The transition metalsubstituted heteropoly compound has the same crystal water as the heteropoly compound, and at the same time, there is stable structural water directly connected to the skeleton structure inside the anion. Therefore, the transition metal-substituted heteropoly compounds have a stable structure and strong thermal stability. In addition, they can also store a large number of electrons, thereby increasing the conductivity and enhancing the catalytic activity and are more widely used in various catalytic oxidation reactions (Santos et al., 2015).

According to relevant literature reports, heteropoly compounds have been involved in various reactions as acidic and redox catalysts. Transition metal-substituted heteropoly compounds have been widely used in the field of catalytic oxidation of organic substances such as alkanes, olefins, alcohols and sulfur-containing compounds, and the catalytic oxidation desulfurization of fuel oil (Zhang et al., 2016). However, for the desulfurization reaction to remove hydrogen sulfide, most 
of the catalysts used are phosphotungstates replaced by vanadium (V). Liu et al. (2017a) and Lütkehoff et al. (1995) found that the efficiency of $\mathrm{H}_{2} \mathrm{~S}$ removal of the pure phosphotungstic acid $\left(\mathrm{H}_{3} \mathrm{PW}_{12} \mathrm{O}_{40}\right)$ and phosphomolybdic acid $\left(\mathrm{H}_{3} \mathrm{PMo}_{12} \mathrm{O}_{40}\right)$ were $20 \%$ and $80 \%$, respectively. Ma et al. (2014) and Wang et al. (2003) substituted the part elements of phosphomolybdic acid with $V$ and W to form $\mathrm{H}_{7}\left[\mathrm{P}_{2} \mathrm{Mo}_{17} \mathrm{VO}_{62}\right] \cdot 39 \mathrm{H}_{2} \mathrm{O}$ and $\mathrm{H}_{3} \mathrm{PW}_{10} \mathrm{Mo}_{2} \mathrm{O}_{40}$ to remove $\mathrm{H}_{2} \mathrm{~S}$. The results showed that the efficiency of $\mathrm{H}_{2} \mathrm{~S}$ removal of them were only $85 \%$. Few studies have used transition metal (Co, $\mathrm{Ni}, \mathrm{Zn}$, etc.) substituted phosphomolybdate to remove hydrogen sulfide in mixed gas.

In summary, we used alkaline degradation to synthesize a series of transition metal monosubstituted heteropoly compounds $\mathrm{H}_{7} \mathrm{PMO}_{11} \mathrm{MO}_{39}\left(\mathrm{M}=\mathrm{Co}^{2+}, \mathrm{Mn}^{2+}, \mathrm{Ni}^{2+}\right.$ and $\left.\mathrm{Zn}^{2+}\right)\left(\mathrm{HPMO}{ }_{11} \mathrm{M}\right)$ and single-absent heteropoly compounds $\mathrm{H}_{3} \mathrm{PMo}_{11} \mathrm{O}_{39}\left(\mathrm{HPMo}_{11}\right)$. They were used to absorb hydrogen sulfide in acid gas. We used Fourier transform infrared spectroscopy (FT-IR), elemental analysis and scanning electron microscopy (SEM) to characterize and analyze the morphology and structure of $\mathrm{HPMO}{ }_{11} \mathrm{M}$. The dynamic absorption experiment was used to test the removal and regeneration performance of $\mathrm{HPMo}{ }_{11} \mathrm{M}$ for hydrogen sulfide. At the same time, conditions optimization experiments were conducted to explore the optimal values of temperature, hydrogen sulfide concentration, heteropoly compound concentration and solution $\mathrm{pH}$. Finally, based on Xray photoelectron spectroscopy (XPS) characterization results, the desulfurization products and desulfurization mechanism were discussed.

\section{EXPERIMENTAL}

\subsection{Materials and Reagents}

Phosphomolybdic acid $\left(\mathrm{H}_{3} \mathrm{PMo}_{12} \mathrm{O}_{40}\right.$, Shanghai Yindian Chemical Co., Ltd., China), Cobalt acetate ( $\left.\mathrm{Co}\left(\mathrm{CH}_{3} \mathrm{CO}_{2}\right)_{2} \cdot 4 \mathrm{H}_{2} \mathrm{O}\right)$, Manganous acetate $\left(\mathrm{Mn}\left(\mathrm{CH}_{3} \mathrm{CO}_{2}\right)_{2} \cdot 4 \mathrm{H}_{2} \mathrm{O}\right)$, Nickel (II) acetate tetrahydrate $\left(\mathrm{Ni}\left(\mathrm{CH}_{3} \mathrm{CO}_{2}\right)_{2} \cdot 4 \mathrm{H}_{2} \mathrm{O}\right)$, zinc acetate $\left(\mathrm{Zn}\left(\mathrm{CH}_{3} \mathrm{CO}_{2}\right)_{2} \cdot 4 \mathrm{H}_{2} \mathrm{O}\right)$, sodium hydroxide $(\mathrm{NaOH})$, hydrochloric acid $(\mathrm{HCl}, 36 \%)$, Barium Chloride $\left(\mathrm{BaCl}_{2} \cdot 2 \mathrm{H}_{2} \mathrm{O}\right)$. All the reagents are of analytical grade and were used as received.

\subsection{Preparation of $\mathrm{HPMo}_{12}, \mathrm{HPMo}_{11}$ and $\mathrm{HPMo}{ }_{11} \mathrm{M}\left(\mathrm{M}=\mathrm{Co}^{2+}, \mathrm{Mn}^{2+}, \mathrm{Ni}^{2+}\right.$ and $\mathrm{Zn}^{2+}$ )}

The preparation process of $\mathrm{H}_{3} \mathrm{PMo}_{12} \mathrm{O}_{40}\left(\mathrm{HPMo}_{12}\right), \mathrm{H}_{3} \mathrm{PMO}_{11} \mathrm{O}_{39}\left(\mathrm{HPMo}_{11}\right)$ and $\mathrm{H}_{7} \mathrm{PMO}_{11} \mathrm{MO}_{39}$ $\left(\mathrm{HPMo}{ }_{11} \mathrm{M}\right)\left(\mathrm{M}=\mathrm{Co}^{2+}, \mathrm{Mn}^{2+}, \mathrm{Ni}^{2+}\right.$ and $\left.\mathrm{Zn}^{2+}\right)$ were performed with reference to the literatures (Tourné et al., 1970; Patel and Pathan, 2012):

$\mathrm{HPMo}_{11}$ : The $\mathrm{pH}$ of a solution of $\mathrm{H}_{3} \mathrm{PMo}_{12} \mathrm{O}_{40}(1.825 \mathrm{~g}, 1 \mathrm{mmol})$ in water $(20 \mathrm{~mL})$ was adjusted to

4.3 using $\mathrm{NaOH}(1 \mathrm{M})$. The aqueous solution was evaporated to obtain $\mathrm{HPMO}_{11}$.

HPMo ${ }_{11} \mathrm{M}$ : The $\mathrm{pH}$ of a solution of $\mathrm{H}_{3} \mathrm{PMo}_{12} \mathrm{O}_{40}(1.825 \mathrm{~g}, 1 \mathrm{mmol})$ in water $(20 \mathrm{~mL})$ was adjusted

to 4.3 using $\mathrm{NaOH}(1 \mathrm{M})$. The solution was heated to $80^{\circ} \mathrm{C}$ by stirring. The corresponding $1 \mathrm{mmoL}$ transition metal acetates $\left(\mathrm{Co}\left(\mathrm{CH}_{3} \mathrm{CO}_{2}\right)_{2} \cdot 4 \mathrm{H}_{2} \mathrm{O}, \mathrm{Mn}\left(\mathrm{CH}_{3} \mathrm{CO}_{2}\right)_{2} \cdot 4 \mathrm{H}_{2} \mathrm{O}\right.$, Ni $\left(\mathrm{CH}_{3} \mathrm{CO}_{2}\right)_{2} \cdot 4 \mathrm{H}_{2} \mathrm{O}$, and $\left.\mathrm{Zn}\left(\mathrm{CH}_{3} \mathrm{CO}_{2}\right)_{2} \cdot 4 \mathrm{H}_{2} \mathrm{O}\right)$ were dissolved in $2 \mathrm{~mL}$ of hot water, and added to the above solution dropwisely. The solution was heated at $80^{\circ} \mathrm{C}$ with stirring for $1.5 \mathrm{~h}$. After filtering, the filtrate was aged for $12 \mathrm{~h}$ to obtain crystals. After filtering again, it was dried at $110^{\circ} \mathrm{C}$ for $4 \mathrm{~h}$ and activated at $200^{\circ} \mathrm{C}$ for $3 \mathrm{~h}$.

\subsection{Characterization Analytical Methods}

The characterization methods used for the catalysts are shown in Table 1.

Table 1. Methods for characterization and analysis of catalysts.

\begin{tabular}{lll}
\hline & Methods & Manufacturer \\
\hline 1 & FT-IR & Thermo Fisher Scientific Corp, USA \\
2 & ICP & Elementar Corp, Germany \\
3 & SEM & Hitachi Limited Corp, Japan \\
4 & XPS & Thermo Fisher Scientific Corp, USA \\
\hline
\end{tabular}




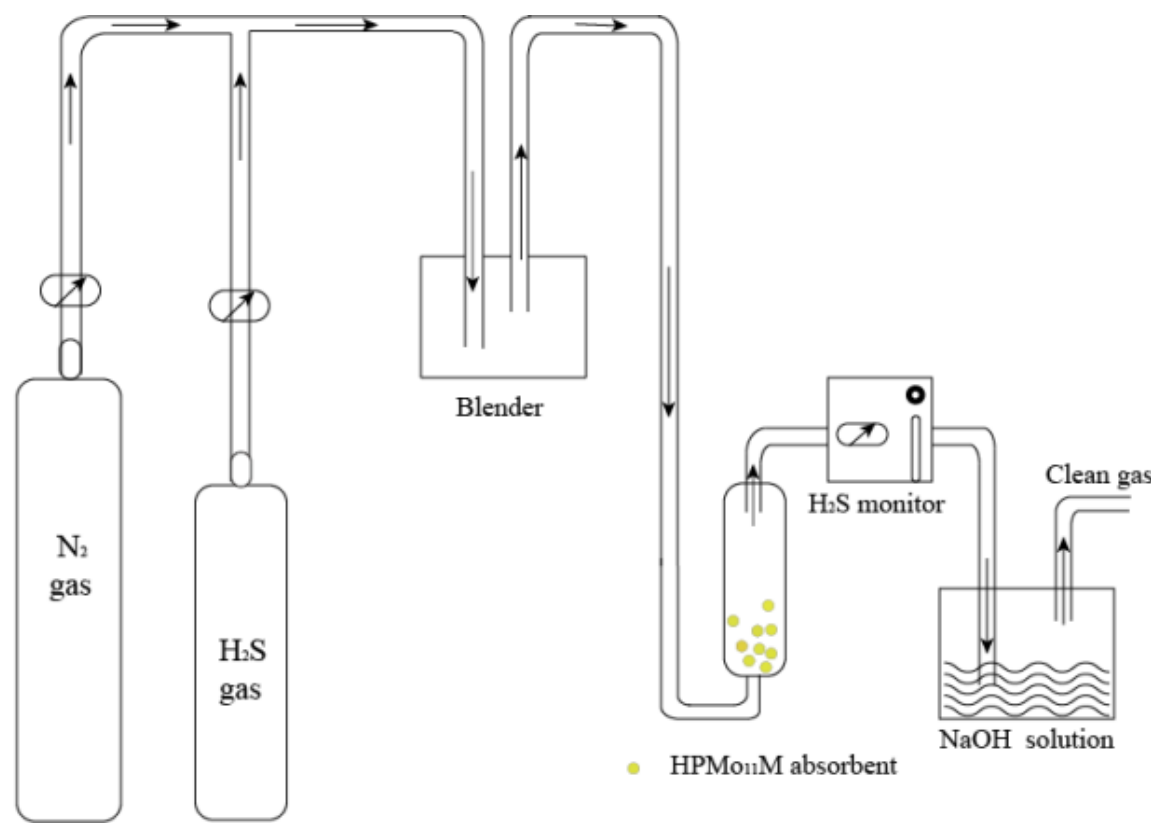

Fig. 1. Reaction device diagram.

\section{4 $\mathrm{H}_{2} \mathrm{~S}$ Absorption and Regeneration Experiments}

The $\mathrm{H}_{2} \mathrm{~S}$ absorption experiment was performed at standard atmospheric pressure. The desulfurization reagent was obtained by dissolving a certain amount of $\mathrm{HPMO}_{11} \mathrm{M}$ in $50 \mathrm{~mL}$ of deionized water and transferring it to a cylindrical glass reactor. The mixture of $\mathrm{N}_{2}$ and $\mathrm{H}_{2} \mathrm{~S}$ was introduced into the glass reactor at a flow rate of $100 \mathrm{~mL} \mathrm{~min}^{-1}$. The $\mathrm{H}_{2} \mathrm{~S}$ concentration was detected by a TH-990s $\mathrm{H}_{2} \mathrm{~S}$ gas analyzer (Liu et al., 2017). The residual $\mathrm{H}_{2} \mathrm{~S}$ gas was absorbed by $\mathrm{NaOH}$ solution. The temperature of the solution during the reaction was controlled by a thermostatic water bath. The effects of different operating parameters on desulfurization were studied by controlled experiments, under $\mathrm{HPMo}_{11} \mathrm{M}$ concentration range of 0.0005 to $0.002 \mathrm{~mol} \mathrm{~L}^{-1}$ and $\mathrm{pH}$ range of 1 to 9 . The reaction device diagram is shown in Fig. 1. The desulfurization performance of $\mathrm{HPMo}_{11} \mathrm{M}$ solutions was mainly evaluated by $\mathrm{H}_{2} \mathrm{~S}$ removal efficiency $(\eta, \%)$ :

$\eta=\frac{C_{0}-C_{t}}{C_{0}}$

where $\mathrm{C}_{0}$ and $\mathrm{C}_{t}$ represent the inlet and outlet concentrations of $\mathrm{H}_{2} \mathrm{~S}$, respectively.

After the reaction, the desulfurizing agent was regenerated and recovered in a water bath at $90^{\circ} \mathrm{C}$ with $500 \mathrm{~mL} \mathrm{~min}^{-1}$ of air continuously for $6 \mathrm{~h}$. The regenerated desulfurizing agent solution can continue to perform $\mathrm{H}_{2} \mathrm{~S}$ desorption experiment.

\section{RESULTS AND DISCUSSION}

\subsection{Characterization}

\subsubsection{FT-IR spectrum of $\mathrm{HPMo}_{12}, \mathrm{HPMo}_{11}$, and $\mathrm{HPMo}{ }_{11} \mathrm{M}\left(\mathrm{M}=\mathrm{Co}^{2+}, \mathrm{Mn}^{2+}, \mathrm{Ni}^{2+}\right.$} and $\left.\mathrm{Zn}^{2+}\right)$.

The Fourier transform infrared spectra (FT-IR) of $\mathrm{HPMo}_{12}, \mathrm{HPMo}_{11}$ and $\mathrm{HPMo}{ }_{11} \mathrm{M}\left(\mathrm{M}=\mathrm{Co}^{2+}\right.$, $\mathrm{Mn}^{2+}, \mathrm{Ni}^{2+}$ and $\mathrm{Zn}^{2+}$ ) are shown in Fig. 2, which are consistent with the characteristic peaks of Keggintype molybdenum heteromeric compounds (Xie et al., 2008). In the FT-IR spectrum of HPMo12, the characteristic peaks at $1059,953,881$, and $747 \mathrm{~cm}^{-1}$ correspond to the stretching vibration peaks of $\mathrm{P}-\mathrm{O}_{a}, \mathrm{Mo}=\mathrm{O}_{d}, \mathrm{Mo}-\mathrm{O}_{b}-\mathrm{Mo}$, and $\mathrm{Mo}-\mathrm{Oc}-\mathrm{Mo}$, respectively. After the transformation from $\mathrm{HPMo}_{12}$ to $\mathrm{HPMo}_{11}$, the four characteristic peaks of $\mathrm{P}-\mathrm{O}_{\mathrm{a}}, \mathrm{Mo}=\mathrm{O}_{d}, \mathrm{Mo}-\mathrm{O}_{\mathrm{b}}-\mathrm{Mo}$ and Mo-Oc-Mo changed significantly. In particular, the $\mathrm{P}-\mathrm{O}_{a}$ bond stretching vibration peak at $1059 \mathrm{~cm}^{-1}$ was split 


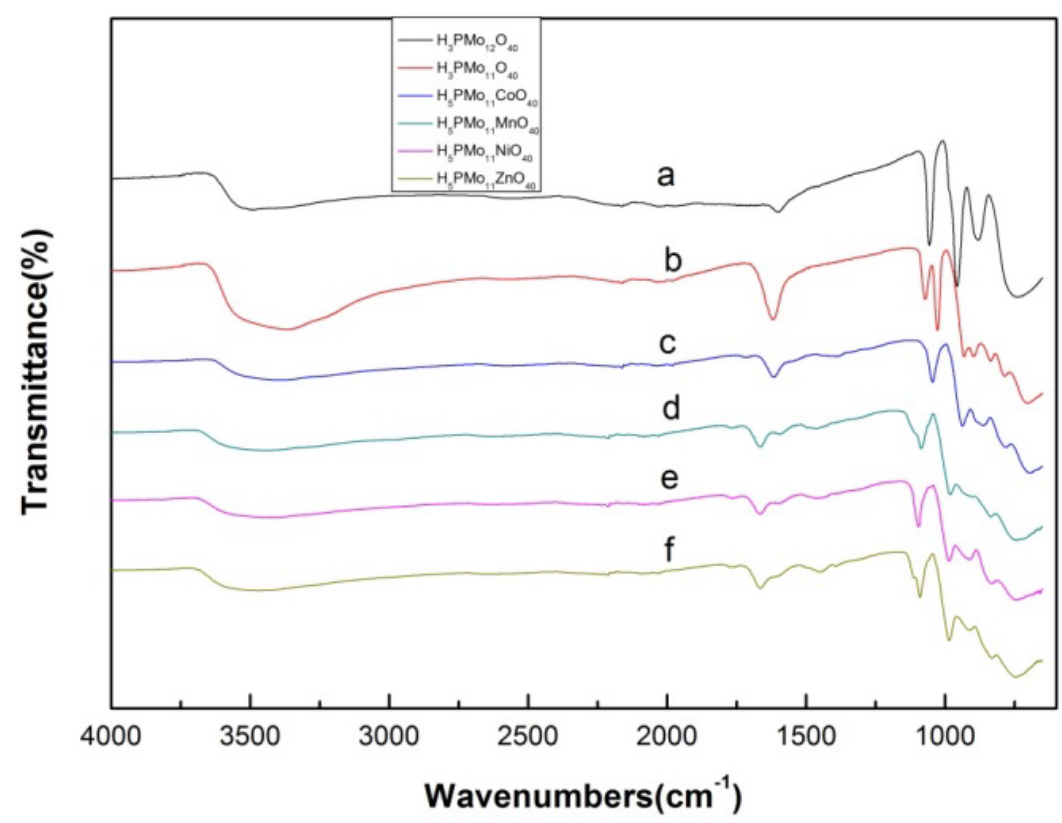

Fig. 2. FT-IR spectra of transition metal substituted heteropoly phosphomolybdate: (a) HPMo ${ }_{12}$, (b) $\mathrm{HPMo}_{11}$, (c) HPMo${ }_{11} \mathrm{Co}$, (d) HPMo ${ }_{11} \mathrm{Mn}$, (e) HPMo11 Ni, (f) HPMo ${ }_{11} \mathrm{Zn}$.

into two vibration absorption peaks $\left(1077\right.$ and $1030 \mathrm{~cm}^{-1}$ ) in the FT-IR spectrum of HPMo11. This phenomenon indicates that after losing a Mo atom, the symmetry of the vibration mode of the heteroatom is reduced due to the destruction of the symmetry around it. From the FT-IR spectrum of $\mathrm{HPMO}_{11} \mathrm{M}$, it can be seen that when the transition metal is bound to HPMo11, the stretching vibration peak of the $\mathrm{P}-\mathrm{O}_{a}$ bond of $\mathrm{HPMo}{ }_{11} \mathrm{M}$ appears near the original position without splitting, indicating that the structure has been restored, that is, the symmetry around the heteroatoms is restored by the metal ions to some extent. The $\mathrm{P}-\mathrm{O}_{a}$ bonds of $\mathrm{HPMO}_{11} \mathrm{M}(\mathrm{M}=$ $\mathrm{Co}^{2+}, \mathrm{Mn}^{2+}, \mathrm{Ni}^{2+}$ and $\left.\mathrm{Zn}^{2+}\right) \mathrm{FT}-\mathrm{IR}$ spectra show stretching vibration peaks at 1049, 1090, 1097 and $1092 \mathrm{~cm}^{-1}$, respectively. The stretching vibration peaks of $\mathrm{Mo}=\mathrm{O}_{d}, \mathrm{Mo}_{\mathrm{o}}-\mathrm{O}_{\mathrm{b}}-\mathrm{Mo}$ and $\mathrm{Mo}-\mathrm{O}_{\mathrm{c}}-\mathrm{Mo}$ also have displacement changes. These results showed that the transition metal ions successfully replaced the Mo atom.

\subsubsection{ICP of HPMo 12 and $\mathrm{HPMO}_{11} \mathrm{Co}$}

The contents of $\mathrm{P}, \mathrm{Mo}$, and $\mathrm{Co}$ in $\mathrm{HPMO}_{12}$ and $\mathrm{HPMo}_{11} \mathrm{Co}$ were determined by an inductively coupled plasma spectrometer (ICP-AES). The results of elemental analysis are shown in Table 2. The experimental values are basically consistent with the theoretical calculations, indicating that Co in $\mathrm{HPMO}_{11}$ Co replaces a Mo.

\subsubsection{Catalyst scanning electron microscope (SEM) analysis}

For the morphological analysis of the $\mathrm{HPMO}_{12}$ and $\mathrm{HPMO}_{11} \mathrm{M}$ (represented by $\mathrm{HPMo}{ }_{11} \mathrm{Co}$ ), their SEM images are shown in Fig. 3. As can be seen in Fig. 3(a), the HPMo 12 is a flat layer structure connected together. After the adding of transition metal cobalt (Co), the morphology becomes prismatic (as shown in Fig. 3(b)), which indicates that the transition metal Co successfully replaced Mo.

Table 2. Analytical results of elements in substituted heteropoly phosphomolybdic acid.

\begin{tabular}{lllll}
\hline & & $\mathrm{P}$ & Mo & Co \\
\hline $\mathrm{HPMO}_{12}$ & experimental values & 1 & 11.76 & - \\
& theoretical calculations & 1 & 12 & - \\
$\mathrm{HPMO}{ }_{11} \mathrm{Co}$ & experimental values & 1 & 10.86 & 1.2 \\
& theoretical calculations & 1 & 11 & 1 \\
\hline
\end{tabular}



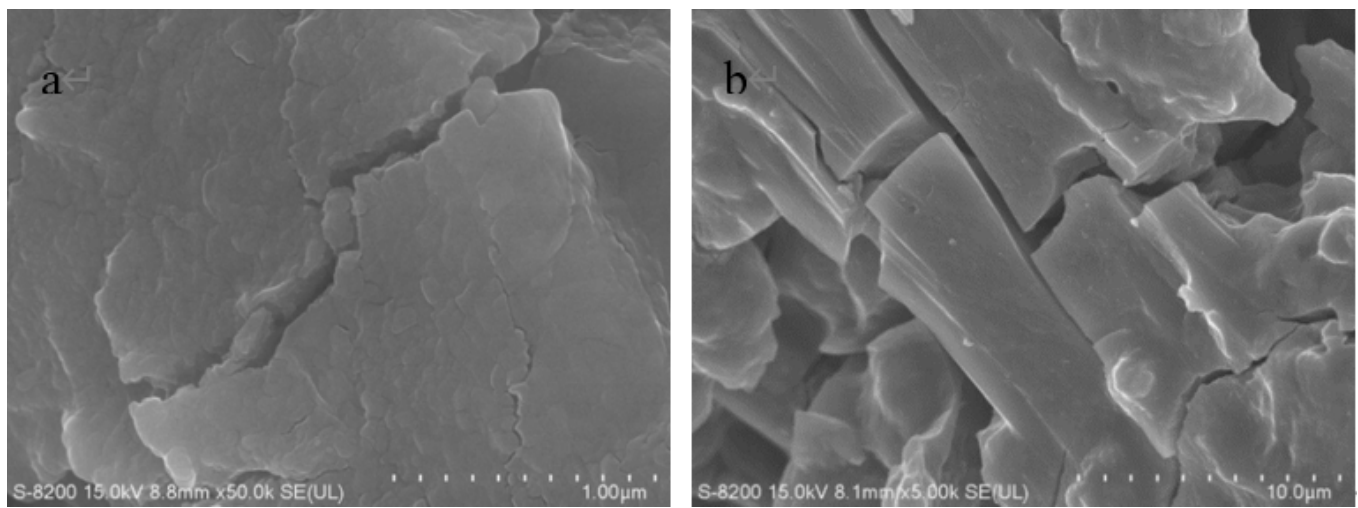

Fig. 3. SEM images of the (a) HPMo 12 and (b) HPMo ${ }_{11} \mathrm{Co}$.

\subsection{Optimization Experiment of $\mathrm{H}_{2} \mathrm{~S}$ Absorption Conditions}

\subsubsection{Effect of transition metal species on $\mathrm{H}_{2} \mathrm{~S}$ removal}

The hydrogen sulfide absorption of $\mathrm{HPMO}_{12}, \mathrm{HPMo} 11$ and $\mathrm{HPMo}{ }_{11} \mathrm{M}\left(\mathrm{M}=\mathrm{Co}^{2+}, \mathrm{Mn}^{2+}, \mathrm{Ni}^{2+}\right.$ and $\mathrm{Zn}^{2+}$ ) were compared under the same conditions, as shown in Fig. 4. Compared with HPMO 12 and vacant $\mathrm{HPMO}_{11}$, the heteropoly phosphomolybdate substituted by transition metal elements had better desulfurization effect and longer duration. Therefore, the focus is on the desulfurization and regeneration performance of heteropoly phosphomolybdate substituted by transition metal elements. The hydrogen sulfide absorption and regeneration results of $\mathrm{HPMO}_{11} \mathrm{Co}, \mathrm{HPMo}{ }_{11} \mathrm{Mn}$, HPMo ${ }_{11} \mathrm{Ni}$ and $\mathrm{HPMO}_{11} \mathrm{Zn}$ are shown in Fig. 5. In comparison, $\mathrm{HPMo}{ }_{11} \mathrm{Co}$ and $\mathrm{HPMo}{ }_{11} \mathrm{Zn}$ had better removal effect on hydrogen sulfide, reaching more than $90 \%$. Comparing the desulfurization performance after regeneration, it was found that $\mathrm{HPMo}{ }_{11} \mathrm{Co}$ had the best effect. According to the comprehensive comparison of desulfurization and regenerated desulphurization effects, the desulfurization ability of heteropoly phosphomolybdate was ranked as follows: $\mathrm{HPMO}_{12}<\mathrm{HPMO}_{11}$ $<\mathrm{HPMo}_{11} \mathrm{Zn}<\mathrm{HPMo}_{11} \mathrm{Ni}<\mathrm{HPMo}_{11} \mathrm{Mn}<\mathrm{HPMo}_{11} \mathrm{Co}$. Therefore, $\mathrm{HPMo}_{11} \mathrm{Co}$ was selected as the desulfurizer for the following condition optimization experiments in this study.

\subsubsection{Effect of temperature on $\mathrm{H}_{2} \mathrm{~S}$ removal}

The temperature of the desulfurizer has a significant effect on $\mathrm{H}_{2} \mathrm{~S}$ removal, and the results are shown in Fig. 6. It can be observed that the desulphurization efficiency of heteropoly

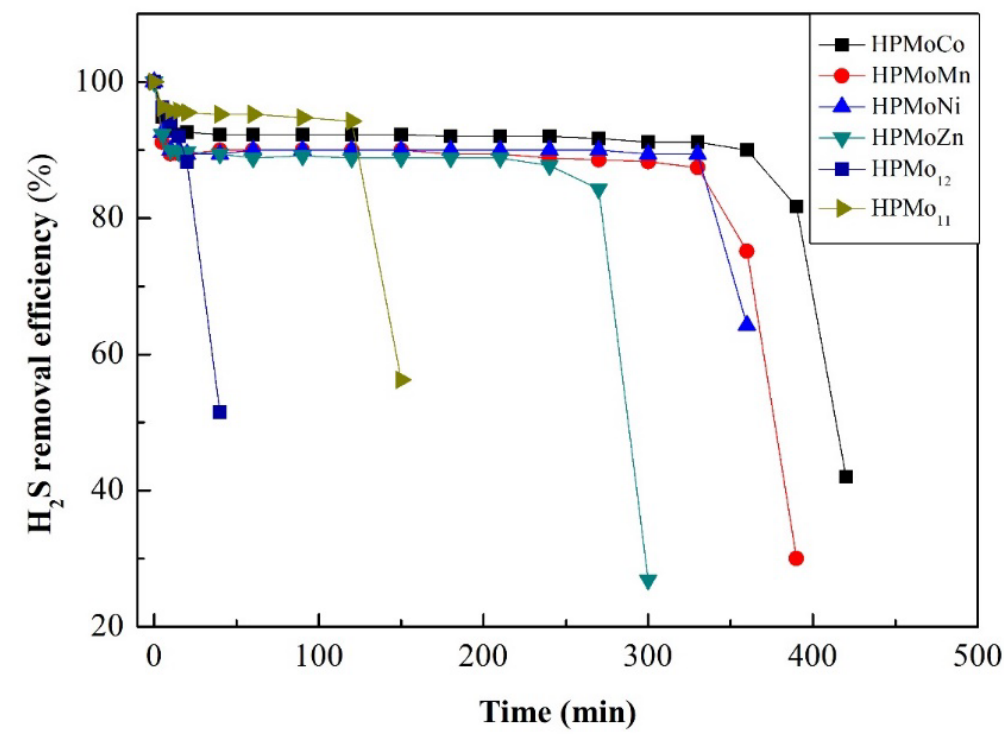

Fig. 4. Removal of $\mathrm{H}_{2} \mathrm{~S}$ in $\mathrm{HPMo}_{12}, \mathrm{HPMo}_{11}$ and $\mathrm{HPMo}{ }_{11} \mathrm{M}\left(\mathrm{M}=\mathrm{Co}^{2+}, \mathrm{Mn}^{2+}, \mathrm{Ni}^{2+}\right.$ and $\left.\mathrm{Zn}^{2+}\right)\left(\mathrm{T}=25^{\circ} \mathrm{C}\right.$, $\mathrm{C}_{\mathrm{HPMo11CO}}=0.001 \mathrm{~mol} \mathrm{~L}^{-1}, \mathrm{C}_{\mathrm{H} 2 \mathrm{~S}}=1750 \mathrm{mg} \mathrm{m}^{-3}$ ). 


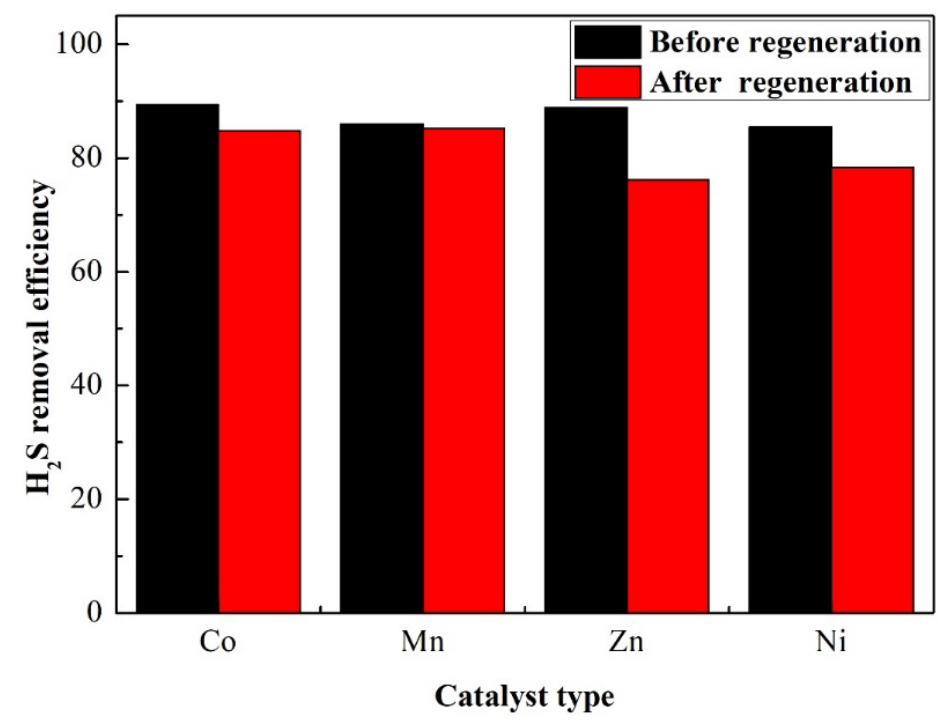

Fig. 5. Research on desulfurization and regeneration performance of $\mathrm{HPMo}{ }_{11} \mathrm{Co}, \mathrm{HPMO}{ }_{11} \mathrm{Mn}$, $\mathrm{HPMo}_{11} \mathrm{Ni}$ and $\mathrm{HPMo}_{11} \mathrm{Zn}$ (Absorption experiment: $\mathrm{T}=25^{\circ} \mathrm{C}, \mathrm{CHPMo}_{11} \mathrm{Co}=0.001 \mathrm{~mol} \mathrm{~L}^{-1}, \mathrm{C}_{\mathrm{H} 2 \mathrm{~S}}=$ $1750 \mathrm{mg} \mathrm{m}^{-3}$; Regeneration experiment: $\mathrm{T}_{\text {air }}=90^{\circ} \mathrm{C}$ ).

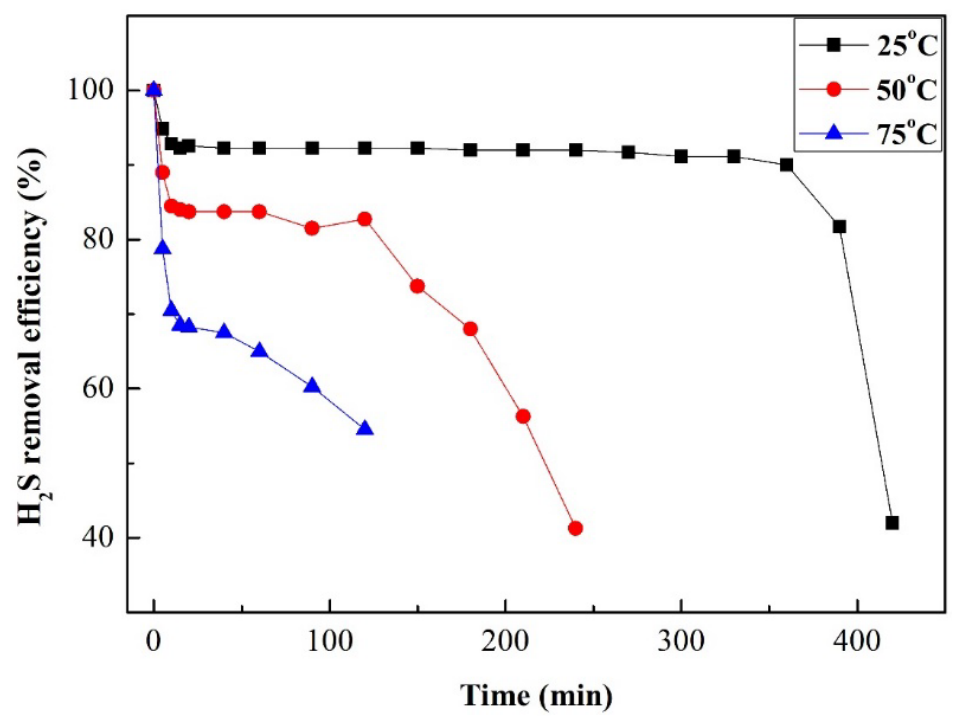

Fig. 6. Effect of temperature on $\mathrm{H}_{2} \mathrm{~S}$ removal $\left(\mathrm{C}_{\mathrm{HPMo}} 11 \mathrm{Co}_{\mathrm{O}}=0.001 \mathrm{~mol} \mathrm{~L}^{-1}, \mathrm{C}_{\mathrm{H} 2 \mathrm{~S}}=1750 \mathrm{mg} \mathrm{m}^{-3}\right)$.

phosphomolybdate decreased significantly with the increase of temperature within the investigated range $\left(25-75^{\circ} \mathrm{C}\right)$. The desulfurizer at room temperature $\left(25^{\circ} \mathrm{C}\right)$ showed the best removal performance, and the desulfurization efficiency can be maintained above $90 \%$ within $350 \mathrm{~min}$. This study also exhibited that higher temperature was not conducive to the removal of $\mathrm{H}_{2} \mathrm{~S}$ mainly in two aspects: on the one hand, the oxidation process of $\mathrm{H}_{2} \mathrm{~S}$ was exothermic, so high temperature was not conducive to the absorption process (Huang et al., 2017); on the other hand, the increase of temperature tended to retard the dissolution of $\mathrm{H}_{2} \mathrm{~S}$ in aqueous solutions. Therefore, the degree of solubility played a leading role in this process. The room temperature $\left(25^{\circ} \mathrm{C}\right)$ was selected as the best desulfurizer temperature, and subsequent experiments were carried out accordingly.

\subsubsection{Effect of $\mathrm{HPMo}_{11} \mathrm{Co}$ concentration on $\mathrm{H}_{2} \mathrm{~S}$ removal}

The effect of $\mathrm{HPMo}{ }_{11} \mathrm{Co}$ concentration on desulfurization performance at $25^{\circ} \mathrm{C}$ is shown in Fig. 7. It can be observed that the higher the concentration of $\mathrm{HPMO}_{11} \mathrm{Co}$, the higher the desulfurization efficiency and the longer the reaction time. At the concentration of $0.0005 \mathrm{~mol} \mathrm{~L}^{-1}$ for the 


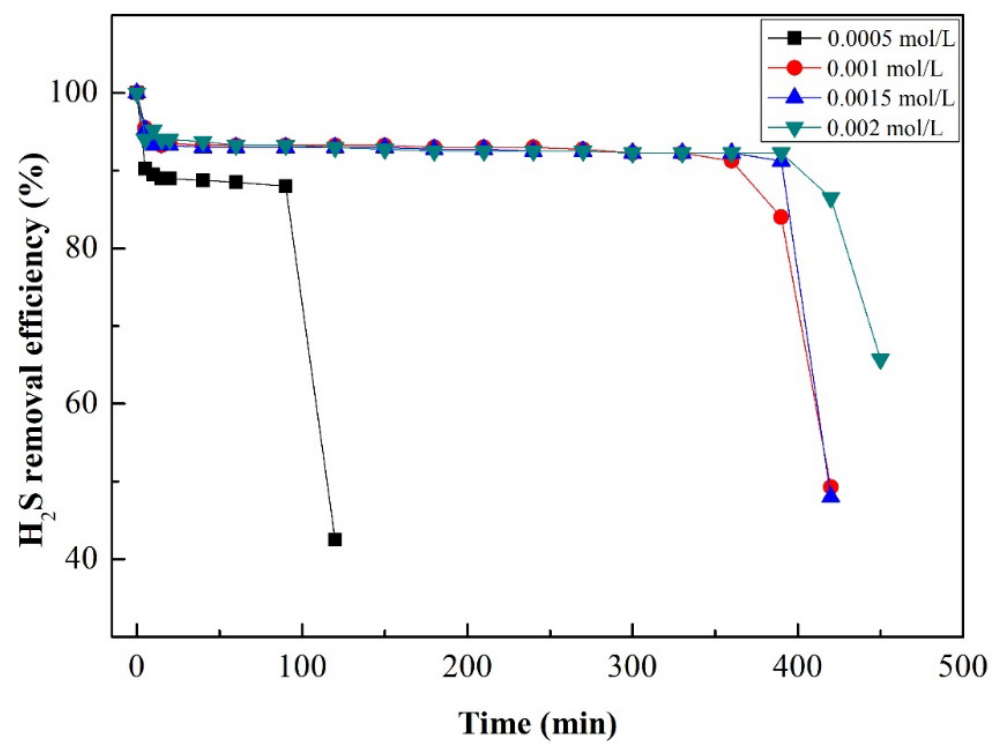

Fig. 7. Effect of $\mathrm{HPMo}_{11} \mathrm{Co}$ concentration on $\mathrm{H}_{2} \mathrm{~S}$ removal $\left(\mathrm{T}=25^{\circ} \mathrm{C}, \mathrm{C}_{\mathrm{H} 2 \mathrm{~S}}=1750 \mathrm{mg} \mathrm{m}^{-3}\right)$.

$\mathrm{HPMO}_{11} \mathrm{Co}$, the desulfurization efficiency decreased rapidly in a short time. When the concentration was $0.001 \mathrm{~mol} \mathrm{~L}^{-1}$, the time for the $\mathrm{H}_{2} \mathrm{~S}$ removal efficiency to remain above $92 \%$ was reduced to $360 \mathrm{~min}$. When the concentration was $0.0015 \mathrm{~mol} \mathrm{~L}^{-1}$, the desulphurization efficiency dropped below $50 \%$ rapidly after $400 \mathrm{~min}$. At the concentration of $\mathrm{HPMo}_{11} \mathrm{Co}$ was $0.002 \mathrm{~mol} \mathrm{~L}^{-1}$, the $\mathrm{H}_{2} \mathrm{~S}$ removal efficiency can be maintained above $92 \%$ within $400 \mathrm{~min}$, and slowly decreased to less than $70 \%$ after $450 \mathrm{~min}$. The desulfurization rate decreased significantly because HPMo ${ }_{11}$ Co was consumed with the extension of the reaction time. In short, the higher the concentration of $\mathrm{HPMO}_{11} \mathrm{Co}$, the more favorable the desulfurization reaction. Therefore, the subsequent experiments were implemented with $0.002 \mathrm{~mol} \mathrm{~L}^{-1}$ of $\mathrm{HPMo}_{11} \mathrm{Co}$.

\subsubsection{Effect of $\mathrm{H}_{2} \mathrm{~S}$ concentration on $\mathrm{H}_{2} \mathrm{~S}$ removal}

The effect of different concentrations of $\mathrm{H}_{2} \mathrm{~S}$ on the desulfurization performance of $\mathrm{HPMO}{ }_{11} \mathrm{Co}$ solution at $25{ }^{\circ} \mathrm{C}$ was studied (Fig. 8). The results showed that the lower the $\mathrm{H}_{2} \mathrm{~S}$ concentration, the more favorable the desulfurization reaction. The desulfurization efficiency can be maintained

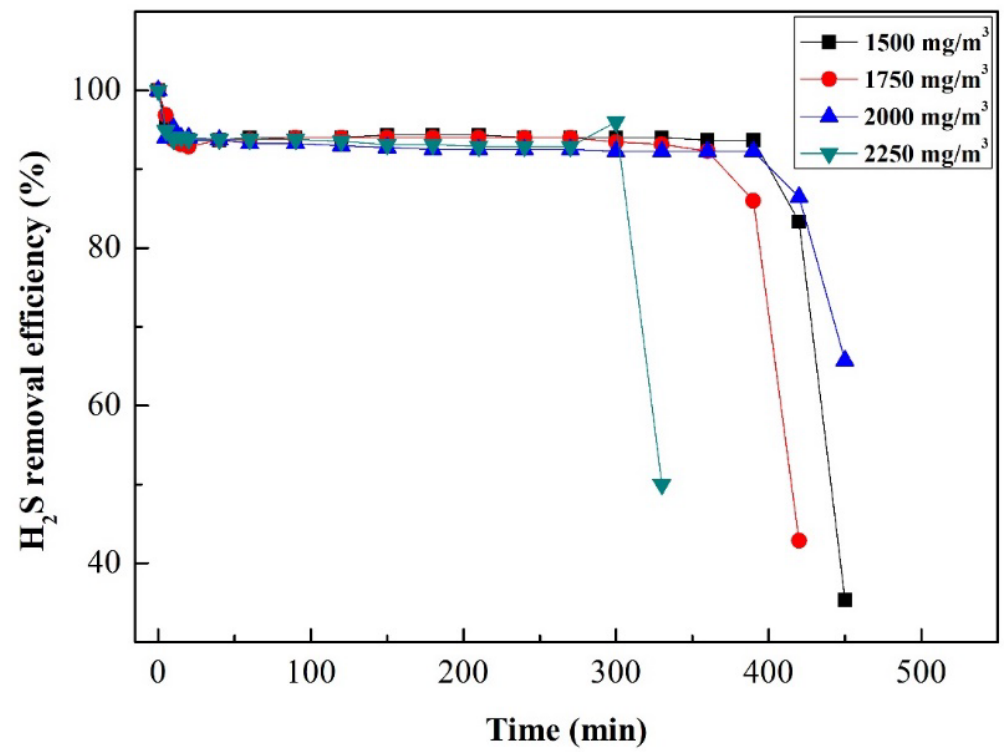

Fig. 8. Effect of $\mathrm{H}_{2} \mathrm{~S}$ concentration on $\mathrm{H}_{2} \mathrm{~S}$ removal $\left(T=25^{\circ} \mathrm{C}, \mathrm{C}_{\mathrm{HPMo11Co}}=0.002 \mathrm{~mol} \mathrm{~L}^{-1}\right)$. 
above $90 \%$ within 350 min at most $\mathrm{H}_{2} \mathrm{~S}$ concentrations. Especially when the concentration of $\mathrm{H}_{2} \mathrm{~S}$ was $1500 \mathrm{mg} \mathrm{m}^{-3}$, the desulfurization efficiency reached above $95 \%$ and the time lasted for $400 \mathrm{~min}$. The reason for this phenomenon is that low concentration of $\mathrm{H}_{2} \mathrm{~S}$ will consume less $\mathrm{HPMo}_{11} \mathrm{Co}$ at the same time. The sudden drop in the desulfurization efficiency at the later stage of the reaction was due to the exhaustion of $\mathrm{HPMo}_{11} \mathrm{Co}$. Combined with actual conditions such as research time and gas flow rate, the subsequent experiments were implemented with $\mathrm{H}_{2} \mathrm{~S}$ concentration of $1750 \mathrm{mg} \mathrm{m}^{-3}$.

\subsubsection{Effect of desulfurizer $\mathrm{pH}$ on $\mathrm{H}_{2} \mathrm{~S}$ removal}

The $\mathrm{pH}$ of desulfurizer is an important factor affecting the removal efficiency of $\mathrm{H}_{2} \mathrm{~S}$ (Zheng et al., 2018). During the research, the $\mathrm{pH}$ of the desulfurizer was adjusted between 1 and 9 with $1 \mathrm{M} \mathrm{NaOH}$ and $1 \mathrm{M} \mathrm{HCl}$, and the $\mathrm{H}_{2} \mathrm{~S}$ concentration was maintained at $1750 \mathrm{mg} \mathrm{m}^{-3}$. As shown in Fig. 9, the removal efficiency of $\mathrm{H}_{2} \mathrm{~S}$ decreased rapidly at the $\mathrm{pH}$ value was 1 and 3 . The removal efficiency of $\mathrm{H}_{2} \mathrm{~S}$ can be maintained above $90 \%$ within $360 \mathrm{~min}$ at the $\mathrm{pH}$ value was 5 . When the $\mathrm{pH}$ value increased from 5 to 9 , the removal efficiency of $\mathrm{H}_{2} \mathrm{~S}$ decreased significantly. This phenomenon may occur because the alkaline environment will destroy the structure of the heteropolyanion, while the heteropolyanion in the acidic environment can maintain a stable keggin-type structure.

Therefore, the $\mathrm{HPMo}_{11} \mathrm{Co}$ solution showed the best desulfurization performance under the optimal conditions $\left(25^{\circ} \mathrm{C}\right.$, the $0.002 \mathrm{~mol} \mathrm{~L}^{-1}$ concentration of $\mathrm{HPMo}{ }_{11} \mathrm{Co}$, the $\mathrm{H}_{2} \mathrm{~S}$ concentration of $1750 \mathrm{mg} \mathrm{m}^{-3}$ and desulfurizer $\mathrm{pH}$ of 5). As shown in Fig. 9, the $\mathrm{H}_{2} \mathrm{~S}$ removal efficiency remained above $90 \%$ within $360 \mathrm{~min}$.

\subsubsection{Absorption kinetics}

The absorption kinetics of the selected optimum conditions was studied. According to the original data of $\mathrm{pH}=5$ curve in Fig. 9, the absorption curve of desulfurizer (the abscissa was time $t$, the ordinate was the outlet concentration $\mathrm{C}_{t}$ ) was made, and it was integrated. The $\mathrm{H}_{2} \mathrm{~S}$ absorption capacity $Q_{t}$ of the desulfurizer $\mathrm{HPMo}_{11} \mathrm{Co}$ at time $\mathrm{t}$ was determined by the above integration results, the $\mathrm{H}_{2} \mathrm{~S}$ flow rate, the $\mathrm{H}_{2} \mathrm{~S}$ inlet concentration $\mathrm{C}_{0}$, and the quality of the desulfurizer $\mathrm{HPMO}_{11} \mathrm{Co}$ :

$Q_{t}=C_{0} t-\int_{0}^{t} C_{t} d t$

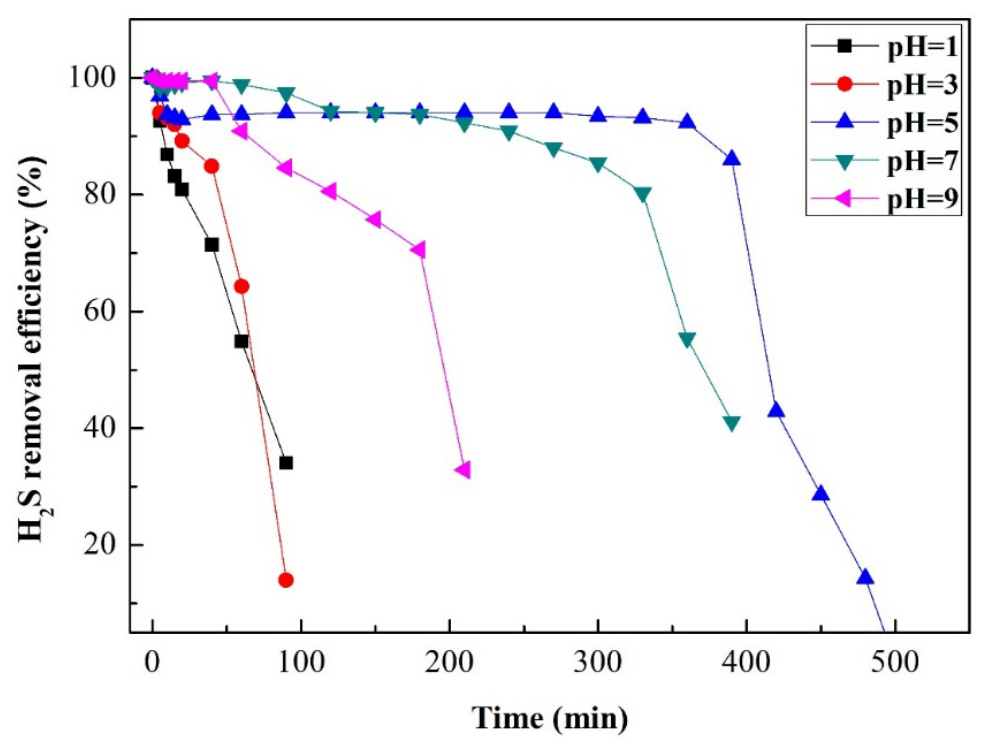

Fig. 9. Effect of desulfurizer $\mathrm{pH}$ on $\mathrm{H}_{2} \mathrm{~S}$ removal $\left(\mathrm{T}=25^{\circ} \mathrm{C}, \mathrm{C}_{\mathrm{HPMo} 11 \mathrm{Co}}=0.001 \mathrm{~mol} \mathrm{~L}^{-1}, \mathrm{C}_{\mathrm{H} 2 \mathrm{~S}}=1750\right.$ $\left.\mathrm{mg} \mathrm{m}^{-3}\right)$. 


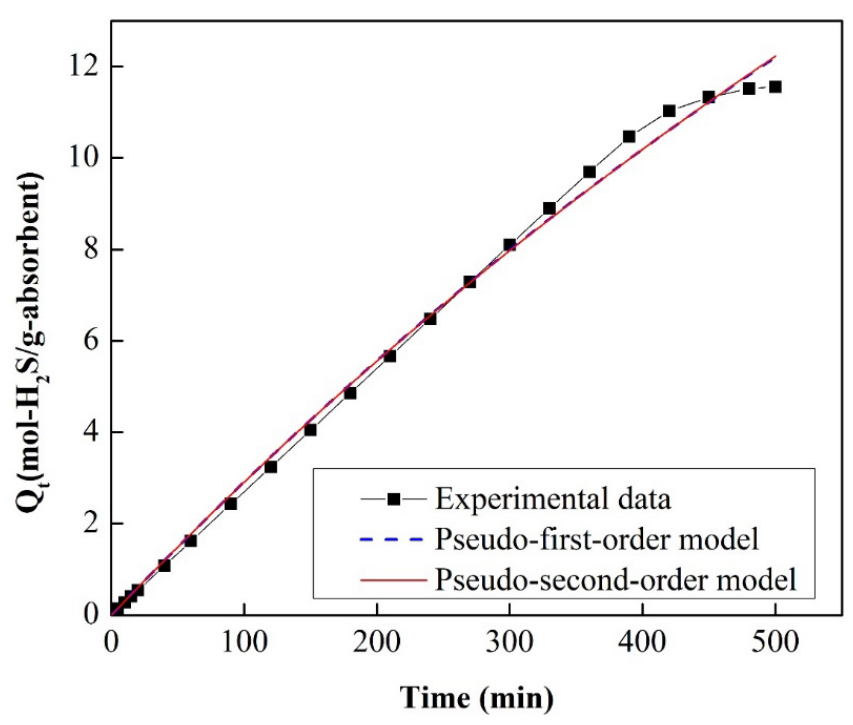

Fig. 10. Kinetic absorption and fitting curves.

Table 3. Pseudo-first-order and pseudo-second-order model parameters of $\mathrm{HPMO}_{11} \mathrm{Co}$.

\begin{tabular}{llllllll}
\hline & \multicolumn{3}{c}{ Pseudo-first-order model } & & \multicolumn{3}{c}{ Pseudo-second-order model } \\
\cline { 1 - 4 } \cline { 6 - 8 } Experiment $\left(\mathrm{Q}_{\mathrm{e}}\right)$ & $\mathrm{k}_{1}$ & $\mathrm{Q}_{\mathrm{e}}$ & $\mathrm{R}^{2}$ & & $\mathrm{k}_{2}$ & $\mathrm{Q}_{\mathrm{e}}$ & $\mathrm{R}^{2}$ \\
\hline 11.5 & $9.27 \times 10^{-4}$ & 32.89 & 0.9963 & & $8.24 \times 10^{-6}$ & 60.93 & 0.9962 \\
\hline
\end{tabular}

Fig. 10 showed kinetic absorption and fitting curves. It could be observed that the $\mathrm{H}_{2} \mathrm{~S}$ absorption of $\mathrm{HPMO}_{11} \mathrm{Co}$ rose rapidly in a short period of time, then the growth rate gradually slowed down, and finally reached saturation. This was consistent with the curve results of the $\mathrm{H}_{2} \mathrm{~S}$ removal efficiency. The concentration of the desulfurizer in the later test decreased, resulting in the reduction of $\mathrm{H}_{2} \mathrm{~S}$ removal efficiency. Finally, the $\mathrm{H}_{2} \mathrm{~S}$ absorption of the desulfurizer reached

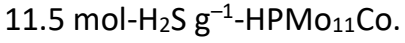

In order to further explore the relationship between the $\mathrm{H}_{2} \mathrm{~S}$ absorption capacity $\mathrm{Q}_{t}$ and the time t, pseudo-first-order (Eq. (3)) and pseudo-second-order (Eq. (4)) kinetic models were used to fit the experimental data:

$Q_{t}=Q_{e}-Q_{e} e^{-k_{1} \times t}$

$Q_{t}=\frac{k_{2} Q_{e}^{2} t}{1+k_{2} Q_{e} t}$

where $\mathrm{Q}_{\mathrm{e}}\left(\mathrm{mol}-\mathrm{H}_{2} \mathrm{~S} \mathrm{~g}^{-1}-\mathrm{HPMo}_{11} \mathrm{Co}\right)$ is the equilibrium absorption capacity of HPMo ${ }_{11} \mathrm{Co}$; $\mathrm{Q}_{\mathrm{t}}$ (mol$\mathrm{H}_{2} \mathrm{~S} \mathrm{~g}^{-1}-\mathrm{HPMO}_{11} \mathrm{Co}$ ) is the absorption capacity at different time $\mathrm{t}(\mathrm{min}) ; \mathrm{k}_{1}$ and $\mathrm{k}_{2}$ are the parameters of pseudo-first-order and pseudo-second-order kinetic models, respectively.

The pseudo-first-order and pseudo-second-order fitting curves of $\mathrm{HPMO}_{11} \mathrm{Co}$ are displayed in Fig. 10, and the fitting constants are given in Table 3. It can be seen that the experimental data can be well described by pseudo-first-order kinetic model with the correlation coefficients $\left(R^{2}=\right.$ 0.9963). In addition, the fitted absorption capacity of the pseudo-first-order model is 32.89 mol-

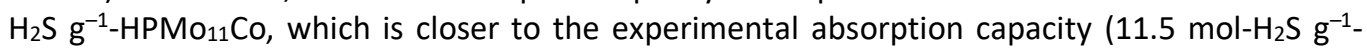
$\mathrm{HPMo}_{11} \mathrm{Co}$ ) than that of the pseudo-second-order model $\left(60.93 \mathrm{~mol}-\mathrm{H}_{2} \mathrm{~S} \mathrm{~g}^{-1}-\mathrm{HPMo}{ }_{11} \mathrm{Co}\right)$. Therefore, pseudo-first-order kinetic model is predominant in the absorption process of $\mathrm{H}_{2} \mathrm{~S}$ in $\mathrm{HPMO}_{11} \mathrm{Co}$ solution.

\subsection{Desulfurization Products and Desulfurization Mechanism}

FT-IR spectroscopy was used to analyze functional groups of HPMo ${ }_{11}$ Co before and after 
desulfurization and regeneration. As shown in Fig. 11, the presence of four characteristics peaks of the heteropoly acid anion after absorption and regeneration, indicating that the compound had stable Keggin-type structure.

The solid powder obtained by evaporating the $\mathrm{HPMo}_{11} \mathrm{Co}$ before and after absorption and regeneration was used for XPS analysis. Fig. 12 showed the XPS spectra of the Mo $3 d_{5 / 2}$ orbital on the surface of the HPMo ${ }_{11} \mathrm{Co}$ compound before absorption as well as before and after regeneration. It can be seen that the valence of heteropoly compounds did not change after the whole process of absorption and regeneration, but it did not mean that Mo atoms did not participate in the reaction (Zhao et al., 1996, 1998). The whole process was as follows: before absorption, the valence of Mo atom in $\mathrm{HPMo}_{11} \mathrm{Co}$ was $+\mathrm{VI}$, and the binding energy of Mo $3 \mathrm{~d}_{5 / 2}$ was $233.09 \mathrm{eV}$; after absorption, the binding energy of Mo $3 \mathrm{~d}_{5 / 2}$ changed and increased by $230.72 \mathrm{eV}$, indicating that Mo became +IV valence. Whereas after high temperature air blow-off regeneration, the binding energy of $\mathrm{Mo} 3 \mathrm{~d}_{5 / 2}$ recovered to $233.42 \mathrm{eV}$, and Mo recovered to $+\mathrm{VI}$

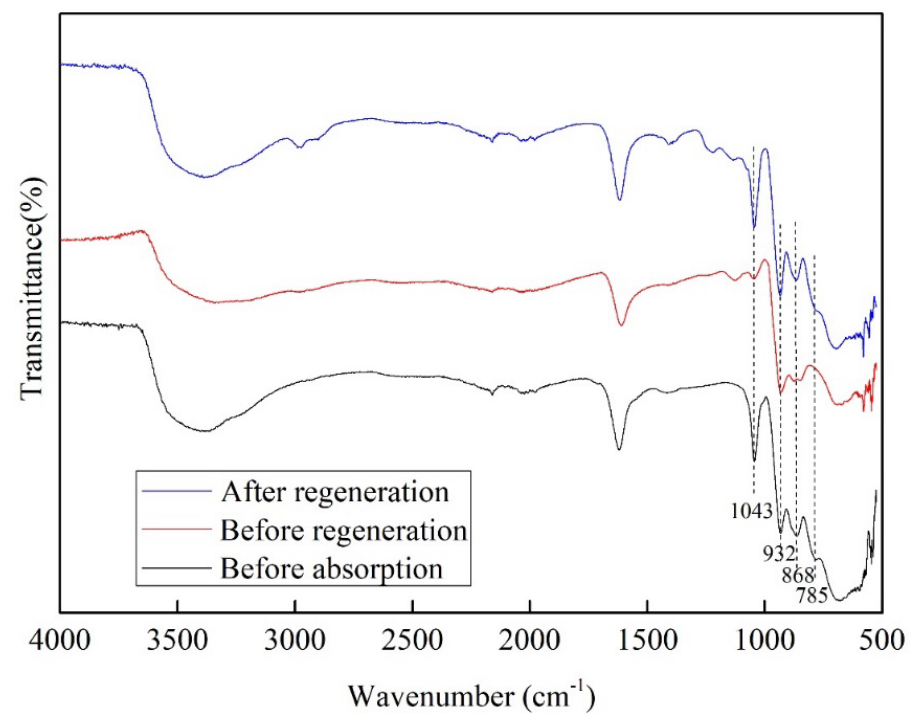

Fig. 11. FT-IR spectra of PrPMo HPMo ${ }_{11}$ Co before and after desulfurization and regeneration.

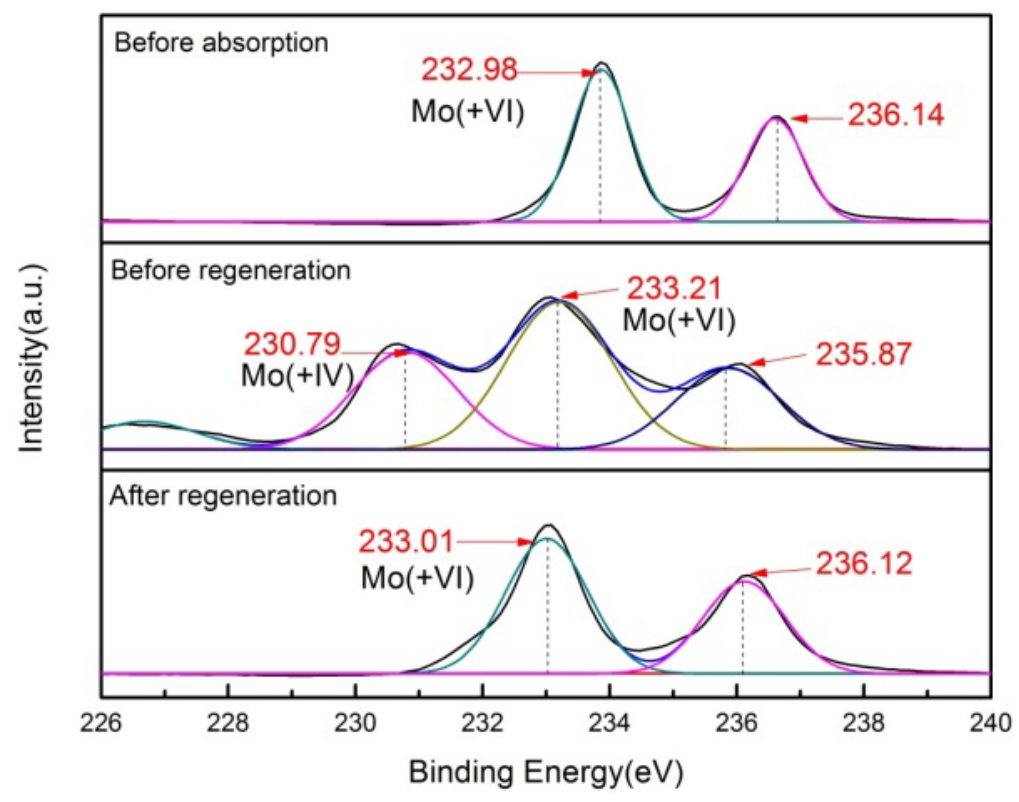

Fig. 12. The XPS spectra of Mo $3 d_{5 / 2}$ in $\mathrm{HPMo}_{11} \mathrm{Co}$ before absorption as well as before and after regeneration. 
valence. XPS spectral characterization results showed that during the absorption of $\mathrm{H}_{2} \mathrm{~S}, \mathrm{Mo}(+\mathrm{VI})$ in $\mathrm{HPMO}_{11} \mathrm{Co}$ was reduced to Mo (+IV), and then oxidized to Mo (+VI) in the process of hightemperature air stripping.

The XPS patterns of the Co $2 \mathrm{p}$ orbital of the HPMo ${ }_{11}$ Co compound surface before absorption as well as before and after regeneration are shown in Fig. 13. Before absorption, the XPS spectra of $\mathrm{Co} 2 \mathrm{P}$ of the sample had two absorption characteristic peaks with binding energies of $783.27 \mathrm{eV}$ and $799.33 \mathrm{eV}$ respectively, indicating that there are two different valence states of Co in the sample before absorption, namely $\mathrm{Co}(+\mathrm{II})$ and $\mathrm{Co}(+\mathrm{III})$. After $\mathrm{H}_{2} \mathrm{~S}$ absorption, the binding energy of Co $2 p$ became $780.78 \mathrm{eV}$, indicating that the valence of Co in this compound was +II. After high temperature air blow-off regeneration, the XPS spectra of Co 2P of the sample recovered two absorption characteristic peaks with the binding energies of $783.32 \mathrm{eV}$ and $799.04 \mathrm{eV}$, indicating that $\mathrm{Co}$ in the sample was oxidized and its valence state was restored. Based on the above characterization results, $\mathrm{Co}(+\mathrm{III})$ in $\mathrm{HPMo}_{11} \mathrm{Co}$ was reduced to $\mathrm{Co}(+\mathrm{II})$ during the absorption process, and then regenerated to $\mathrm{Co}$ (+III) through high-temperature air stripping (Khassin et al., 2001; Le et al., 2016).

The XPS spectra of the S $2 p$ orbital of solid powder obtained by evaporating HPMo ${ }_{11}$ Co before and after regeneration are shown in Fig. 14. Among them, a characteristic absorption peak with the binding energy of $162.32 \mathrm{eV}$ illustrated that $\mathrm{H}_{2} \mathrm{~S}$ had been absorbed. At this time, the valence of the element S was -II. The characteristic absorption peak with the binding energy of 163.76 $\mathrm{eV}$ indicated that $\mathrm{S}(-\mathrm{II})$ had changed into $\mathrm{S}(0)$. The characteristic absorption peak at $169.07 \mathrm{eV}$ indicated the presence of $\mathrm{S}(+\mathrm{VI})$ in the solution. After high-temperature air stripping regeneration, the characteristic absorption peak areas of $\mathrm{S}$ and $\mathrm{S}(+\mathrm{VI})$ increased significantly, indicating that the desulfurization product contained S elementary substance and S (+VI) (Liu et al., 2017; Liu and Wang, 2017b, c). The $\mathrm{BaCl}_{2}$ solution was added to the regenerated solution to prove that $\mathrm{S}$ $(+\mathrm{VI})$ was $\mathrm{SO}_{4}{ }^{2-}$, since white precipitation was observed. The calculation of the peak areas showed that elemental sulfur $\mathrm{S}$ accounted for $55 \%$, and $\mathrm{SO}_{4}{ }^{2-}$ accounted for $45 \%$. Therefore, the peak area ratio was $11: 9$, so that the molar ratio of $\mathrm{S}$ and $\mathrm{SO}_{4}{ }^{2-}$ was estimated to be approximately $11: 9$. $\mathrm{S}$ was not oxidized to produce $\mathrm{SO}_{4}{ }^{2-}$. At the beginning, the concentration of transition metal monosubstituted heteropoly compounds $\left(\mathrm{M}=\mathrm{Co}^{2+}, \mathrm{Mn}^{2+}, \mathrm{Ni}^{2+}\right.$ and $\left.\mathrm{Zn}^{2+}\right)$ was high and the oxidation was strong, which could convert hydrogen sulfide into $\mathrm{SO}_{4}{ }^{2-}$. As the reaction proceeded, the concentration of transition metal mono-substituted heteropoly compounds decreased and the oxidation became weak, and hydrogen sulfide could be converted into $\mathrm{S}$. In addition, carbon disulfide $\left(C_{2}\right)$ is known to be a very good solvent of sulfur, which can extract elemental sulfur from desulfurization products at room temperature, so as to achieve the purpose of separating $\mathrm{S}$ and $\mathrm{SO}_{4}{ }^{2-}$.

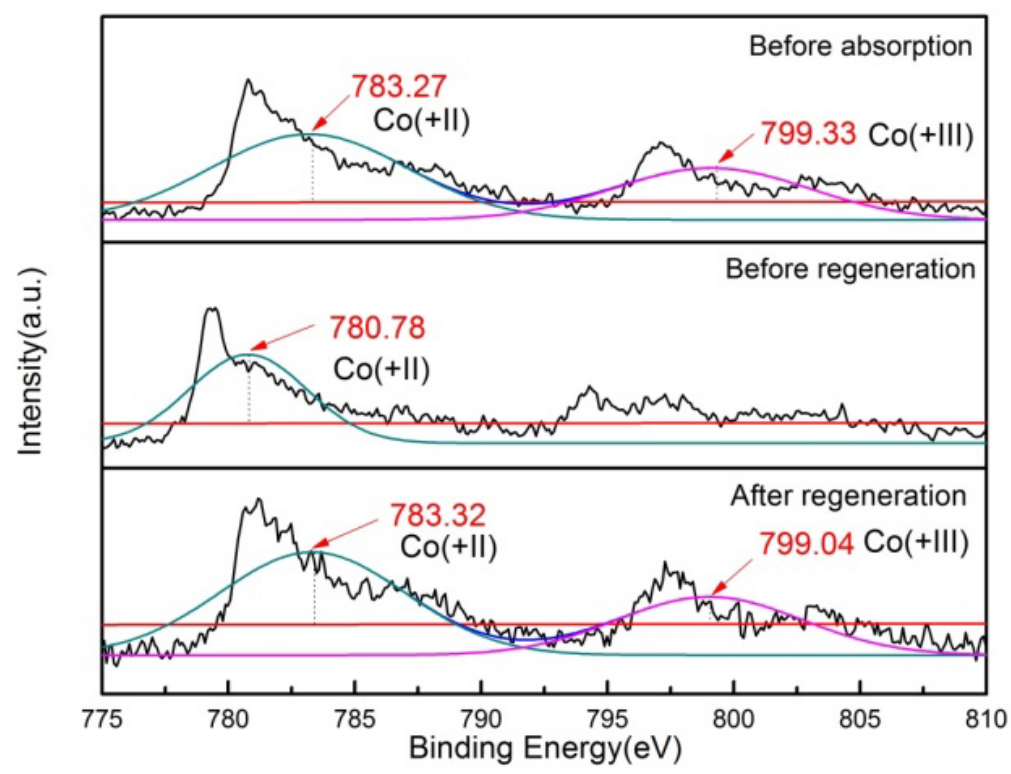

Fig. 13. The XPS spectra of Co $2 \mathrm{P}$ orbitals on the surface of $\mathrm{HPMO}_{11} \mathrm{Co}$ compound. 


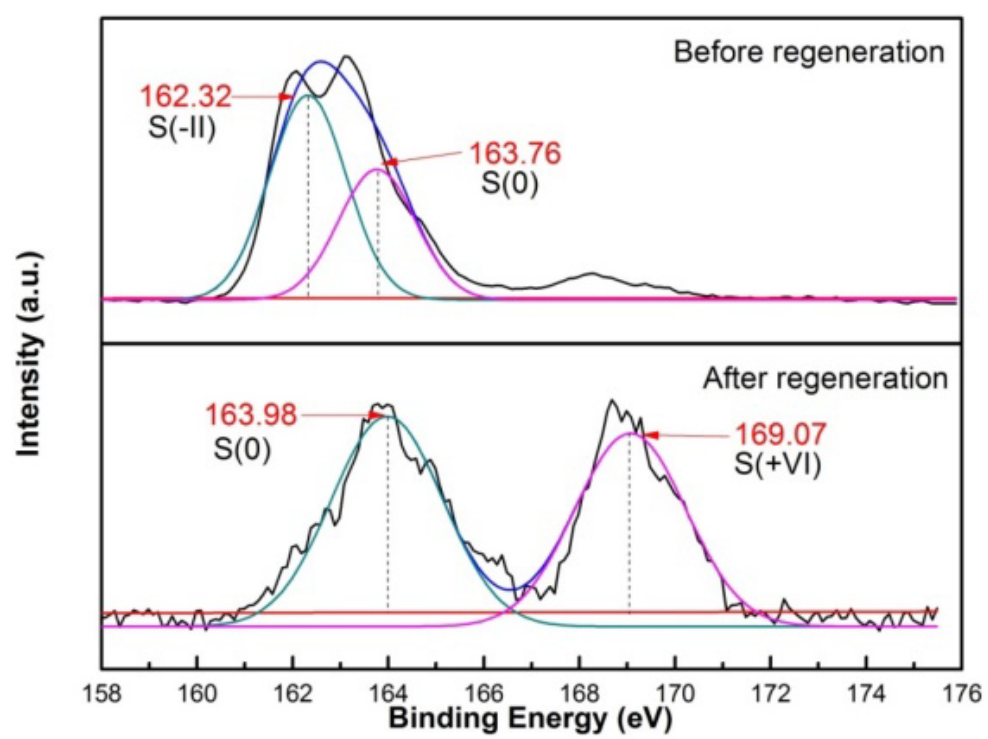

Fig. 14. XPS spectra of S $2 p$ of HPMo ${ }_{11}$ Co before and after regeneration.

Table 4. Surface element compositions of $\mathrm{HPMo}_{11} \mathrm{Co}$ before absorption as well as before and after regeneration.

\begin{tabular}{lllll}
\hline Name & Co & Mo & P & S \\
\hline Before absorption & $9.4 \%$ & $79.7 \%$ & $10.9 \%$ & 0 \\
Before regeneration & $4.2 \%$ & $41.6 \%$ & $5.5 \%$ & $48.7 \%$ \\
After regeneration & $7.6 \%$ & $66.4 \%$ & $10.9 \%$ & $15.1 \%$ \\
\hline
\end{tabular}

Table 5. Comparison with other desulfurizers for $\mathrm{H}_{2} \mathrm{~S}$.

\begin{tabular}{lll}
\hline Desulfurizers & Efficiency of $\mathrm{H}_{2} \mathrm{~S}$ removal & References \\
\hline $\mathrm{H}_{3} \mathrm{PMo}_{12} \mathrm{O}_{40}$ & $80 \%$ & Lütkehoff et al. (1995) \\
$\mathrm{H}_{3} \mathrm{PW}_{12} \mathrm{O}_{40}$ & $20 \%$ & Liu et al. $(2017 \mathrm{a})$ \\
$\left(\mathrm{NH}_{4}\right)_{11}\left[\mathrm{Sm}_{\left(\mathrm{PMo}_{11} \mathrm{O}_{39}\right)_{2}}\right.$ & $80 \%$ & Liu et al. $(2017 \mathrm{a})$ \\
$\mathrm{H}_{7}\left[\mathrm{P}_{2} \mathrm{MO}_{17} \mathrm{VO}_{62}\right] \cdot 39 \mathrm{H}_{2} \mathrm{O}$ & $85 \%$ & Ma et al. $(2014)$ \\
$\mathrm{H}_{3} \mathrm{PW}_{10} \mathrm{Mo}_{2} \mathrm{O}_{40}$ & $85 \%$ & Wang et al. (2003) \\
$\mathrm{H}_{7} \mathrm{PMo}_{11} \mathrm{CoO}_{39}$ & $92 \%$ & This work \\
\hline
\end{tabular}

We used XPS to analyze surface element compositions of $\mathrm{HPMO}_{11} \mathrm{Co}$ before absorption as well as before and after regeneration, including $\mathrm{Co}, \mathrm{Mo}, \mathrm{P}$, and $\mathrm{S}$ elements, and calculated the relative composition content as shown in Table 4. It can be seen that the surface of HPMo ${ }_{11}$ Co did not contain $\mathrm{S}$ element before the absorption of $\mathrm{H}_{2} \mathrm{~S}$, but after the absorption of $\mathrm{H}_{2} \mathrm{~S}$, the content of $\mathrm{S}$ element on the surface of $\mathrm{HPMo}_{11} \mathrm{Co}$ increased to $48.7 \%$, and the content of S element on the surface of $\mathrm{HPMO}_{11} \mathrm{Co}$ was $15.1 \%$ after regeneration. This indicated that the surface of the regenerated HPMo ${ }_{11}$ Co was covered by a small amount of $S$, leading to a decrease in the desulfurization rate after regeneration.

The absorption performance of $\mathrm{H}_{7} \mathrm{PMO}_{11} \mathrm{CoO}_{39}$ for $\mathrm{H}_{2} \mathrm{~S}$ was compared with the previous desulfurizers as listed in Table 5. $\mathrm{H}_{7} \mathrm{PMo}_{11} \mathrm{CoO}_{39}$ exhibited higher efficiency of $\mathrm{H}_{2} \mathrm{~S}$ removal than other desulfurizers, illustrating that the absorption performance of metal mono-substituted heteropoly compounds had been improved in this work.

\section{CONCLUSION}

We studied the desulfurization performance of a series of transition metal monosubstituted 
heteropoly phosphomolybdate and mono-vacancy heteropoly phosphomolybdate under different reaction conditions. The major results were concluded as follows:

(1) Multiple characterization results confirmed the successful synthesis of $\mathrm{H}_{3} \mathrm{PMO}_{12} \mathrm{O}_{40}, \mathrm{H}_{7} \mathrm{PMO}_{11} \mathrm{O}_{39}$ and $\mathrm{H}_{7} \mathrm{PMO}_{11} \mathrm{MO}_{39}\left(\mathrm{M}=\mathrm{Co}^{2+}, \mathrm{Mn}^{2+}, \mathrm{Ni}^{2+}\right.$ and $\left.\mathrm{Zn}^{2+}\right)$.

(2) $\mathrm{H}_{7} \mathrm{PMO}_{11} \mathrm{CoO}_{39}$ had the best desulfurization performance and regeneration effect and was selected as the most suitable desulfurizer. Its solution had the best desulfurization capability at $25^{\circ} \mathrm{C}$. The removal efficiency of hydrogen sulfide by the desulfurizer could reach $90 \%$ within $400 \mathrm{~min}$. The higher the concentration of $\mathrm{H}_{7} \mathrm{PMO}_{11} \mathrm{CoO}_{39}$, the higher the removal efficiency of hydrogen sulfide.

(3) Low $\mathrm{H}_{2} \mathrm{~S}$ concentration was conducive to the progress of the desulfurization reaction. $\mathrm{H}_{7} \mathrm{PMO}_{11} \mathrm{CoO}_{39}$ showed the highest desulfurization efficiency at $\mathrm{pH}$. The study on the desulfurization absorption kinetics under optimal conditions showed that the process fitted into the pseudo-first-order kinetic model, and the correlation coefficient $\left(R^{2}\right)$ was 0.9963 .

(4) The final products of desulfurization were $\mathrm{S}$ and $\mathrm{SO}_{4}{ }^{2-} . \mathrm{H}_{7} \mathrm{PMo}_{11} \mathrm{CoO}_{39}$ played a redox role in the desulfurization process, which could convert $\mathrm{H}_{2} \mathrm{~S}$ into sulfur resources.

\section{ACKNOWLEDGEMENT}

This work was supported by the Natural Science Foundation of China [Nos: 21276144, 21511130021], the Key Research and Development Program of Shandong Province, China [2017GSF217006], and Foundation of State Key Laboratory of High-efficiency Utilization of Coal and Green Chemical Engineering [No: 2017-K30].

\section{REFERENCES}

Bi, L.H., Reicke, M., Kortz, U., Keita, B., Nadjo, L., Clark, R.J. (2004). First structurally characterized palladium (II)-substituted polyoxoanion: $\left[\mathrm{CS}_{2} \mathrm{Na}\left(\mathrm{H}_{2} \mathrm{O}\right)_{10} \mathrm{Pd}_{3}\left(\alpha-\mathrm{Sb}^{11 \mid} \mathrm{W}_{9} \mathrm{O}_{33}\right)_{2}\right]^{9-}$. Inorg. Chem. 43, 3915-3920. https://doi.org/10.1021/ic049736d

Huang, K., Zhang, X.M., Zhou, L.S., Tao, D.J., Fan, J.P. (2017). Highly efficient and selective absorption of $\mathrm{H}_{2} \mathrm{~S}$ in phenolic ionic liquids: A cooperative result of anionic strong basicity and cationic hydrogen-bond donation. Chem. Eng. Sci. 173, 253-263. https://doi.org/10.1016/j.ce s.2017.07.048

Khassin, A.A., Yurieva, T.M., Kaichev, V.V., Bukhtiyarov, V.I., Budneva, A.A., Paukshtis, E.A., Parmon, V.N. (2001). Metal-support interactions in cobalt-aluminum co-precipitated catalysts: XPS and CO adsorption studies. J. Mol. Catal. A: Chem. 175, 189-204. https://doi.org/10.1016/ S1381-1169(01)00216-3

Le, L., Zhang, X., Ma, A., Zhang, Y., Huang, H., Lin, S. (2016). Facile synthesis of Pd/PDDA$\mathrm{GN} / \mathrm{PMO}_{11}$ Co composite and its enhanced catalytic performance for formic acid oxidation. RSC Adv. 6, 107370-107378. https://doi.org/10.1039/C6RA21497E

Liu, X., Li, J., Wang, R. (2017a). Desulfurization and regeneration performance of heteropoly compound/ionic liquid solutions at high temperature. Chem. Eng. J. 316, 171-178. https://doi.org/10.1016/j.cej.2017.01.093

Liu, X., Wang, R. (2017b). An innovative approach to oxidative removal of hydrogen sulfide using the solution of peroxo heteropolyacid. Aerosol Air Qual. Res. 17, 1341-1346. https://doi.org/ 10.4209/aaqr.2016.12.0550

Liu, X., Wang, R. (2017c). $\mathrm{H}_{2} \mathrm{~S}$ removal by peroxo heteropoly compound/ionic liquid solution. Fuel Process. Technol. 160, 78-85. https://doi.org/10.1016/j.fuproc.2017.02.024

Lütkehoff, S., Neumann, M., Ślebarski, A. (1995). 3d and 4d x-ray-photoelectron spectra of $\operatorname{Pr}$ under gradual oxidation. Phys. Rev. B 52, 13808. https://doi.org/10.1103/PhysRevB.52.13808

$\mathrm{Ma}, \mathrm{Y}$., Wang, R. (2014). $\mathrm{H}_{2} \mathrm{~S}$ absorption capacity and regeneration performance of amine Febased ionic liquid. Chem. J. Chin. Univ. 35, 760-765. https://en.cnki.com.cn/Article_en/CJFDT otal-GDXH201404017.htm (in Chinese)

Patel, A., Pathan, S. (2012). Keggin-type cesium salt of first series transition metal-substituted phosphomolybdates: one-pot easy synthesis, structural, and spectral analysis. J. Coord. Chem. 65, 3122-3132. https://doi.org/10.1080/00958972.2012.710843 
Proust, A., Thouvenot, R., Gouzerh, P. (2008). Functionalization of polyoxometalates: Towards advanced applications in catalysis and materials science. Chem. Commun. 16, 1837-1852. https://doi.org/10.1039/B715502F

Santos, F.M., Brandão, P., Félix, V., Nogueira, H.I., Cavaleiro, A.M. (2015). Synthesis and properties of new materials with cobalt (II), iron (III) and manganese (III)-substituted Keggin polyoxotungstates and 1-alkyl-3-methylimidazolium cations. Polyhedron 101, 109-117. https://doi.org/10.1016/j.poly.2015.07.032

Tourné, C.M., Tourné, G.F., Malik, S., Weakley, T. (1970). Triheteropolyanions containing copper (II), manganese (II), or manganese (III). J. Inorg. Nucl. Chem. 32, 3875-3890. https://doi.org/10.101 6/0022-1902(70)80566-8

Wang, R., Gao, H. (2003). Heteropoly acid as new liquid redox absorbent for low sulfur containing gas sweetening. Macro Rev. 16, 141-145. https://doi.org/10.11286/jmr1988.16.141

Weakley, T., Malik, S. (1967). Heteropolyanions containing two different heteroatoms-I. J. Inorg. Nucl. Chem. 29, 2935-2944. https://doi.org/10.1016/0022-1902(67)80126-X

Xie, Q., Wang, X. (2008). Catalytic oxidation of cyclohexene to trans-1,2-cyclohexanediol with mono-substituted keggin-phosphomolybdic acid catalyst. Petrkchem. Technol. 5, 18-21. http://en.cnki.com.cn/Article_en/CJFDTOTAL-SYHG200805016.htm (in Chinese)

Zhang, Y., Wu, L., Dong, X., Wu, P., Hu, H., Xue, G. (2016). Copper (II)-substituted polyoxotungstates immobilized on amine-functionalized SBA-15: Efficient heterogeneous catalysts for liquid phase oxidative reaction. Catal. Lett. 146, 2468-2477. https://doi.org/10.1007/s10562-0161874-7

Zhao, Y., Bao, X., Wang, X., Zhu, Y. (1996). Removal of hzsand recovery of sulfurfrom gas strems by chemical absorption using 12-molybdosilicic acid solution. Acta Sci. Tech. 16, 82-89. http://www.cnki.com.cn/Article/CJFDTOTAL-HJXX601.011.htm (in Chinese)

Zhao, Y., Zhu, Q., Gu, G. (1998). Combined removal of $\mathrm{SO}_{2}, \mathrm{H}_{2} \mathrm{~S}$ and NOx from gas streams by chemical absorption with aqueous solution of 12-molybdophosphoric acid and its reduced species. Water Air Soil Pollut. 102, 157-176. https://doi.org/10.1023/A:1004956032764

Zheng, W., Wu, D., Feng, X., Hu, J., Zhang, F., Wu, Y.T., Hu, X.B. (2018). Low viscous Protic ionic liquids functionalized with multiple Lewis Base for highly efficient capture of $\mathrm{H}_{2} \mathrm{~S}$. J. Mol. Liq. 263, 209-217. https://doi.org/10.1016/j.molliq.2018.04.129 